\title{
A protocol for the dental management of von Willebrand's disease, haemophilia $A$ and haemophilia $B$
}

\author{
M. Stubbs, ^ J Lloyd $\dagger$
}

\begin{abstract}
A guide for the dental management of the three inherited bleeding disorders, von Willebrand's disease, haemophilia $A$ and haemophilia $B$, was established jointly by the Institute of Medical and Veterinary Science Transfusion and Haemostasis Unit in conjunction with the Medically Compromised Dental Unit at the Adelaide Dental Hospital. This protocol was subjected to a successful trial for 24 months.
\end{abstract}

Key words: Haemophilia A, haemophilia B, von Willebrand's factor, tranexamic acid, factor VIII, factor IX.

(Received for publication February 1999. Revised June 1999. Accepted June 1999.)

\section{Introduction}

The primary role of haemostasis is to defend the integrity of blood circulation. Once the haemostatic plug is formed, wound healing can follow. The formation of a haemostatic plug is a complex physiological process involving the interaction between two major processes, platelet aggregation and blood coagulation.

Platelets are anucleate disc-shaped cells that circulate in the bloodstream. When the blood vessel wall is injured and haemorrhage occurs, platelets in the vicinity change shape to a more spherical form with pseudopodia and become 'sticky', such that they readily adhere to the surfaces of damaged tissues. Platelet to platelet adhesion then occurs, leading to a platelet aggregate that forms the basis of the initial haemostatic plug and blood flow through the damaged vessel wall ceases. The coagulation factors are activated by a series of interactions known as the coagulation cascade, leading to the formation of strands of fibrin that are deposited throughout the haemostatic plug, greatly strengthening

\footnotetext{
*Senior Dental Consultant, Clinic 1.4, Medically Compromised Dental Unit, Adelaide Dental Hospital, South Australia.

†Senior Specialist, Division of Haematology, Institute of Medical and Veterinary Science, South Australia.
}

it. The contractile protein in the platelets then draws on the strands of fibrin to cause contraction of the platelet-fibrin mass, further stabilizing it. Fibrinolysis may then break down some of the fibrin in a process of remodelling. This process relies on the conversion of plasminogen to plasmin that degrades the fibrin strands to soluble products.

Haemophilia A is caused by diminished levels of factor VIII and accounts for about 85 per cent of haemophilia patients. It has an incidence of $1: 5,000$ in the male population. Haemophilia B is caused by diminished levels of factor IX, and accounts for about 15 per cent of haemophilia patients. It has an incidence of $1: 15,000$ in the male population. Other defects in coagulation proteins are rare, but deficiency states occur for each of the other blood coagulation factors. ${ }^{1}$ Differing genetic mutation(s) result in a variation in the severity of haemophilia.

Von Willebrand's disease is caused by deficiencies in von Willebrand's factor, which plays a crucial role in the adhesion of platelets to the sub-endothelium during vascular injury and is essential for normal primary haemostasis to occur. Von Willebrand's factor circulates in a non-covalent complex with factor VIII. ${ }^{2}$

There are three subtypes of von Willebrand's disease. Type 1 represents the classic and most common variant of von Willebrand's disease and is characterized by a reduced quantity of circulating von Willebrand's factor. The synthesis of von Willebrand's factor is not impaired, but the release of von Willebrand's factor multimers is inhibited by some unknown mechanism. In type 2 cases, there is a defect in function rather than amount of von Willebrand's factor. In type 3 cases, the levels of von Willebrand's factor are zero or undetectable. ${ }^{3}$

The dental management of any patient with a bleeding disorder should involve a joint interaction between the patient's dentist and haematologist. An established protocol for the management of haemophilia and von Willebrand's patients has been established for oral surgical procedures. However, 
Table 1. Protocol for haemophilia A

\begin{tabular}{|c|c|c|c|}
\hline $\begin{array}{l}\text { Haemophilia A } \\
\text { Factor VIIIc levels }\end{array}$ & $\begin{array}{l}\text { Mild } \\
>5 \mathrm{U} / \mathrm{dl}\end{array}$ & $\begin{array}{l}\text { Moderate } \\
5-2 \mathrm{U} / \mathrm{dl}\end{array}$ & $\begin{array}{l}\text { Severe } \\
<2 \mathrm{U} / \mathrm{dl}\end{array}$ \\
\hline \multicolumn{4}{|l|}{ Procedure ${ }^{\star}$} \\
\hline Local anaesthetic infiltration & No pretreatment required & No pretreatment required & No pretreatment required \\
\hline $\begin{array}{l}\text { Local anaesthetic Inferior } \\
\text { alveolar nerve block }\end{array}$ & No pretreatment required & $\begin{array}{l}\text { Factor VIII at } 10 \mathrm{U} / \mathrm{kg} \\
\text { pretreatment }\end{array}$ & $\begin{array}{l}\text { Factor VIII at } 10 \mathrm{U} / \mathrm{kg} \\
\text { pretreatment }\end{array}$ \\
\hline Supragingival scale only & No pretreatment required & No pretreatment required & $\begin{array}{l}\text { A pretreatment dose of } 1 \mathrm{~g} \text { only, } \\
\text { oral tranexamic acid capsules }\end{array}$ \\
\hline $\begin{array}{l}\text { Subgingival scale or a } \\
\text { restorative procedure } \\
\text { requiring a matrix band }\end{array}$ & $\begin{array}{l}\text { A pretreatment dose of } 1 \mathrm{~g} \text {, } \\
\text { oral tranexamic acid capsules } \\
\text { followed by } 1 \mathrm{~g} \text { qid for } 24 \\
\text { hours post-treatment }\end{array}$ & $\begin{array}{l}\text { Factor VIII at } 7 \mathrm{U} / \mathrm{kg} \text { and a } \\
\text { pretreatment dose of } 1 \mathrm{~g} \text {, } \\
\text { oral tranexamic acid capsules } \\
\text { followed by } 1 \mathrm{~g} \text { qid for } \\
3 \text { days post-treatment }\end{array}$ & $\begin{array}{l}\text { Factor VIII at } 7 \mathrm{U} / \mathrm{kg} \text { and a } \\
\text { pretreatment dose of } 1 \mathrm{~g} \text {, oral } \\
\text { tranexamic acid capsules } \\
\text { followed by } 1 \mathrm{~g} \text { qid for } \\
3 \text { days post-treatment. }\end{array}$ \\
\hline $\begin{array}{l}\text { Minor soft tissue } \\
\text { abscess/swelling } \dagger\end{array}$ & $\begin{array}{l}\text { Factor VIII at } 10 \mathrm{U} / \mathrm{kg} \\
\text { pretreatment }\end{array}$ & $\begin{array}{l}\text { Factor VIII at } 10 \mathrm{U} / \mathrm{kg} \\
\text { pretreatment }\end{array}$ & $\begin{array}{l}\text { Factor VIII at } 10 \mathrm{U} / \mathrm{kg} \\
\text { pretreatment }\end{array}$ \\
\hline
\end{tabular}

^Prior to dental treatment, the patient may not require pretreatment management, factor VIII, oral tranexamic acid capsules or a combination of both.

†Discussion with haematologist is required before any treatment is undertaken.

for the majority of dental procedures not requiring the raising of a mucoperiosteal flap or tooth extraction, the process of determining which dental procedures require the patient to have a preoperative infusion of factor VIII or oral tranexamic capsules is often unclear. A protocol has been devised as a supplement to the existing protocol for management of patients with haemophilia A (Table 1), haemophilia B (Table 2) and von Willebrand's disease (Table 3).

\section{Materials and methods}

The age range of patients who had dental treatment following this protocol was 18-70 years. All children and adolescent patients underwent dental treatment at the Adelaide Women's and Children's Hospital.

In all cases, before any patient underwent dental treatment, the advice of a specialist haematologist was sought at the time of dental examination. Each patient had an initial consultation to determine what dental treatment was required. Depending on the patient's state of oral health, they were placed on either a three- or six-month recall system for review examinations. The severity of the patient's haemophilia status and their previous dental management experience were taken into account.

The dental procedures performed involved all aspects of restorative dentistry and, where appropriate, the level of coagulation factor and/or oral tranexamic acid was adjusted if a matrix band or a wedge was used, increasing the trauma to gingival tissues.

The severity of trauma associated with removal of calculus was also graded according to likely soft tissue trauma associated with the procedure; supragingival calculus removal was considered less traumatic than subgingival calculus removal.

Oral tranexamic acid was prescribed at a dose of $1 \mathrm{~g}, 60$ minutes prior to the dental procedure, then, as $1 \mathrm{~g}$ qid. Nausea is a frequent side-effect of this medication and the dose can be reduced to $1 \mathrm{~g}$ tds or further to $1 \mathrm{~g}$ bd if the nausea is producing a patient compliance problem with taking the medication.

\section{Results}

The South Australia data base records 130 patients with haemophilia A, 16 patients with

Table 2. Protocol for haemophilia B

\begin{tabular}{|c|c|c|c|}
\hline $\begin{array}{l}\text { Haemophilia B } \\
\text { Factor IX levels }\end{array}$ & $\begin{array}{l}\text { Mild } \\
>5 \mathrm{U} / \mathrm{dl}\end{array}$ & $\begin{array}{l}\text { Moderate } \\
2-5 \mathrm{U} / \mathrm{dl}\end{array}$ & $\begin{array}{l}\text { Severe } \\
<2 \mathrm{U} / \mathrm{dl}\end{array}$ \\
\hline \multicolumn{4}{|l|}{ Procedure ${ }^{\star}$} \\
\hline $\begin{array}{l}\text { Local anaesthetic infiltration } \\
\text { Local anaesthetic }\end{array}$ & No pretreatment required & No pretreatment required & No pretreatment required \\
\hline \multirow[t]{2}{*}{ Inferior alveolar nerve block } & No pretreatment required & Prothrombinex-HT & Prothrombinex-HT \\
\hline & & $20 \mathrm{U} / \mathrm{kg}$ pretreatment & $20 \mathrm{U} / \mathrm{kg}$ pretreatment \\
\hline Supragingival scale only & No pretreatment required & No pretreatment required & $\begin{array}{l}\text { A pretreatment dose of } 1 \mathrm{~g} \text { only } \\
\text { oral tranexamic acid capsules }\end{array}$ \\
\hline $\begin{array}{l}\text { Subgingival scale or a } \\
\text { restorative procedure } \\
\text { requiring a matrix band }\end{array}$ & $\begin{array}{l}\text { A pretreatment dose of } 1 \mathrm{~g} \\
\text { oral tranexamic acid capsules } \\
\text { followed by a dose of } 1 \mathrm{~g} \text { qid } \\
\text { for } 24 \text { hours only post-treatment }\end{array}$ & $\begin{array}{l}\text { Prothrombinex-HT } 14 \mathrm{U} / \mathrm{kg} \\
\text { and a pretreatment dose of } \\
1 \mathrm{~g} \text { oral tranexamic acid } \\
\text { capsules followed by a dose } \\
\text { of } 1 \mathrm{~g} \text { qid for } 3 \text { days post-treatment }\end{array}$ & $\begin{array}{l}\text { Prothrombinex-HT } 14 \mathrm{U} / \mathrm{kg} \text { and a } \\
\text { pretreatment dose of } 1 \mathrm{~g} \text { oral } \\
\text { tranexamic acid capsules } \\
\text { followed by a dose of } 1 \mathrm{~g} \text { qid } \\
\text { for } 3 \text { days post-treatment }\end{array}$ \\
\hline Minor soft tissue & Prothrombinex-HT & Prothrombinex-HT & Prothrombinex-HT \\
\hline abscess/swelling $\dagger$ & $20 \mathrm{U} / \mathrm{kg}$ & $20 \mathrm{U} / \mathrm{kg}$ & $20 \mathrm{U} / \mathrm{kg}$ \\
\hline
\end{tabular}

*Prior to dental treatment, the patient may not require pretreatment management, Prothrombinex-HT or oral tranexamic acid capsules. $\nmid$ Discussion with haematologist is required before any treatment is undertaken. 
Table 3. Protocol for von Willebrand's disease (Type 1)

\begin{tabular}{|c|c|c|c|}
\hline $\begin{array}{l}\text { von Willebrand's disease } \\
\text { vWF levels } \\
\text { Factor VIII levels }\end{array}$ & $\begin{array}{l}\text { Mild } \\
>30 \mathrm{U} / \mathrm{dl} \\
>30 \mathrm{U} / \mathrm{dl}\end{array}$ & $\begin{array}{l}\text { Moderate } \\
10-30 \mathrm{U} / \mathrm{dl} \\
10-30 \mathrm{U} / \mathrm{dl}\end{array}$ & $\begin{array}{l}\text { Severe } \\
<10 \mathrm{U} / \mathrm{dl} \\
<10 \mathrm{U} / \mathrm{dl}\end{array}$ \\
\hline \multicolumn{4}{|l|}{ Procedure $^{\star}$} \\
\hline $\begin{array}{l}\text { Local anaesthetic infiltration } \\
\text { Local anaesthetic }\end{array}$ & No pretreatment required & No pretreatment required & No pretreatment required \\
\hline Inferior alveolar nerve block & No pretreatment required & No pretreatment required & $\begin{array}{l}\text { Factor VIII at } 10 \mathrm{U} / \mathrm{kg} \\
\text { pretreatment }\end{array}$ \\
\hline Supragingival scale only & No pretreatment required & No pretreatment required & $\begin{array}{l}\text { A pretreatment dose of } 1 \mathrm{~g} \text { only } \\
\text { oral tranexamic acid capsules }\end{array}$ \\
\hline $\begin{array}{l}\text { Subgingival scale or a } \\
\text { restorative procedure } \\
\text { requiring the use of a } \\
\text { matrix band }\end{array}$ & $\begin{array}{l}\text { A pretreatment dose of } 1 \mathrm{~g} \\
\text { oral tranexamic acid capsules } \\
\text { followed by a dose of } 1 \mathrm{~g} \text { qid for } \\
24 \text { hours post-treatment only }\end{array}$ & $\begin{array}{l}\text { A pretreatment dose of } 1 \mathrm{~g} \text {, } \\
\text { oral tranexamic acid capsules } \\
\text { followed by a dose of } 1 \mathrm{~g} \text { qid for } \\
24 \text { hours post-treatment only }\end{array}$ & $\begin{array}{l}\text { Factor VIII at } 7 \mathrm{U} / \mathrm{kg} \text { and a } \\
\text { pretreatment dose of } 1 \mathrm{~g} \text { oral } \\
\text { tranexamic acid capsules followed } \\
\text { by a dose of } 1 \mathrm{~g} \text { qid for } 3 \text { days } \\
\text { post-treatment }\end{array}$ \\
\hline Minor soft tissue abscess/swelling $\dagger$ & Desmopressin pretreatment & $\begin{array}{l}\text { Factor VIII at } 10 \mathrm{U} / \mathrm{kg} \text { or } \\
\text { desmopressin pretreatment }\end{array}$ & $\begin{array}{l}\text { Factor VIII at } 10 \mathrm{U} / \mathrm{kg} \\
\text { pretreatment }\end{array}$ \\
\hline
\end{tabular}

*Prior to dental treatment, the patient may not require pretreatment factor VIII, oral tranexamic acid capsules, desmopressin or a combination of these.

†Discussion with haematologist is required before any treatment is undertaken.

haemophilia B and 85 patients with von Willebrand's disease. Over the 24-month period, approximately 30 patients with haemophilia $\mathrm{A}$, one patient with haemophilia B and 15 patients with von Willebrand's disease were treated to the protocol outlined in Tables 1-3.

On completion of dental treatment, all patients were taken to the Adelaide Dental Hospital's Oral Maxillofacial Surgery Unit recovery room. Patients were observed for 60 minutes to ensure any blood oozing had ceased. This routine postoperative assessment also included patients who did not require any form of pretreatment prior to dental procedure.

No patient had a postoperative complication associated with bleeding following dental treatment and in most cases, the gingival blood ooze had ceased within the first 60 minutes after treatment. Several patients with severe haemophilia A reported mild gingival ooze postoperatively for several hours.

\section{Discussion}

The following protocols are a guide for determining dental pretreatment and posttreatment requirements for patients with haemophilia A, haemophilia B and von Willebrand's disease (type 1). Each bleeding disorder is categorized on the basis of mild, moderate or severe based on the patient's known plasma levels for the relevant coagulation factor. There are no recognized definitions for the severity grades for type 1 von Willebrand's disorder, but the authors devised a grading for the purposes of this protocol. The levels chosen to categorise von Willebrand's disease into mild, moderate or severe are arbitrary and a guide only. The levels of von Willebrand's factor in a patient change due to the variability of the assay technique used, as well as fluctuations within the patient. Therefore, an average level of von
Willebrand's factor was taken for each patient and used as a guide to classify the patient's von Willebrand's disease as mild, moderate or severe.

These subcategories are listed at the top of each table. Routinely used dental procedures are listed in the left column on the basis of increasing degrees of trauma to oral soft tissues.

Oral tranexamic acid was prescribed at a dose of 1g, 60 minutes prior to the dental procedure, then as $1 \mathrm{~g}$ qid. Nausea is a frequent side-effect and the dose can be reduced to $1 \mathrm{~g}$ tds or further to $1 \mathrm{~g}$ bd if the nausea is producing a patient compliance problem with taking the medication.

Tranexamic acid inhibits the activation of plasmin, thereby reducing fibrinolysis. Reduction of fibrinolytic activity may enhance haemostasis by preventing this process from weakening the haemostatic plug. Hence, tranexamic acid given orally can be used as an adjunct in those patients in whom bleeding may be troublesome. ${ }^{4}$

If replacement of factors VIII or IX was required, this was by intravenous infusion of factor VIII concentrate or factor IX concentrate. These concentrates are prepared from plasma donated to the Australian Red Cross Blood Service and processed by CSL Bioplasma (Broadmeadows, Vic). At the time of evaluation of this protocol, the factor VIII concentrate was 'AHF', an intermediate purity preparation. Currently, factor VIII produced by recombinant technology is available in Australia for some patients. The use of Prothrombinex-HT in haemophilia $B$ has been largely replaced in Australia by a chromatographically purified factor IX concentrate, MonoFIX (CSL Bioplasma, Broadmeadows, Vic), manufactured from blood plasma.

Desmopressin (1-deamino-8-D-arginine vasopressin), also known as DDAVP, increases the 
plasma levels of factor VIII and von Willebrand's factor, presumably by inducing release from stores in endothelial cells. It is usually administered intravenously or subcutaneously at a dose of $0.3 \mu \mathrm{g} / \mathrm{kg}$ over a 20 -minute period, reaching a peak plasma therapeutic level in 30-60 minutes following infusion. ${ }^{5}$ Desmopressin gives a good response in most patients with the milder type 1 von Willebrand's disease. In the more severe cases of von Willebrand's disease (type 2), it is wise to check the response by a formal desmopressin infusion test, in which the plasma levels of factor VIII and von Willebrand's factor are measured at, say, 30-, 60and 120-minute intervals after a test infusion of desmopressin. Desmopressin is ineffective in the rare cases of type 3 von Willebrand's disease.

Although not used in the current study's protocol in haemophilia, desmopressin can be useful in mild haemophilia A. However, its effectiveness in raising the plasma factor VIII level should be checked by a test infusion. It is not useful in severe haemophilia A because there are no tissue stores of factor VIII in haemophilia of this severity. ${ }^{6,7}$

Factor VIII, Prothrombinex-HT and desmopressin infusion was organized by the Institute of Medical and Veterinary Science Transfusion and Haemostasis Unit 60 minutes prior to commencement of the dental procedure.

\section{Conclusions}

A protocol for use in routine dental procedures is described. It has proven very useful in the Adelaide
Dental Hospital and should provide a guide for those involved in the dental treatment of haemophilia and von Willebrand's patients.

The dental management of any patient with a bleeding disorder must be undertaken in conjunction with a haematologist.

\section{References}

1. Brettler DB, Levine PH. Clinical manifestations and therapy of inherited coagulation deficiencies. In: Coleman RW, Hirsh J, Marder VJ, Salzman EW, eds. Haemostasis and thrombosis. Basic principles and clinical practice, $3 \mathrm{rd}$ edn. Philadelphia: Lippincott, 1994:169-183.

2. Montgomery RR, Coller BS. Von Willebrand disease. In: Coleman RW, Hirsh J, Marder VJ, Salzman EW, eds. Haemostasis and thrombosis. Basic principles and clinical practice, 3rd edn. Philadelphia:Lippincott, 1994:134-168.

3. Zimmerman TS, Ruggeri ZM. Von Willebrand's disease. In: Cotran RS, KumarV, Robbins SL, eds. Pathologic basis of disease, 4th edn. Philadelphia: WB Saunders, 1989:696-698

4. Johnson W, Leary J. Management of dental patients with bleeding disorders. Review and update. Oral Surg Oral Med Oral Pathol 1988;66:297-303.

5. Mannucci P. Desmopressin: the first 20 years. Blood 1997;90:2515-2521.

6. Wall U, Jern S, Tengborn L, Jern C. Evidence of a local mechanism for desmopressin-induced tissue type plasminogen activator release in human forearm. Blood 1998;91:529-537.

7. Cohen A, Kessler C. Treatment of inherited coagulation disorders. Am J Med 1995;99:675-682.

Address for correspondence/reprints:

Dr Michael Stubbs

Department of Oral Medicine

School of Dental Science

University of Melbourne

Melbourne, Victoria 3000 